\title{
Richard Green Founding Editor Essay Award (2017) and Other Matters
}

\author{
Kenneth J. Zucker ${ }^{1}$
}

Published online: 11 January 2019

(c) Springer Science+Business Media, LLC, part of Springer Nature 2019

In 2017, the Archives of Sexual Behavior launched the annual Richard Green Founding Editor Essay Award for an article published in Archives judged to be the best "think piece" of the year on gender and/or sexual behavior (Zucker, 2017).

The winning essay was chosen by a multidisciplinary committee of Editorial Board members, and the winner will receive an award of $\$ 1000$. The Committee for 2017 consisted of six members: Khytam Dawood, Eric Janssen, Gu Li, Spencer Olmstead, Wang Ivy Wong, and myself. The Committee short-listed 12 papers and then voted using the Hare system and retained the top five papers. In Round 2, we then voted again using the Hare system.

For Round 2, two papers were deemed by the Committee to be so close in ranking that we decided to give the award to both authors: Chivers (2017) and Seto (2017). Congratulations to both.

\section{Editorial Board (2019)}

I am also pleased to announce several new members of the Editorial Board: Rhonda Balzarini, Aaron J. Blashill, Sara B. Chadwick, Samantha J. Dawson, Christina Dyar, M. Paz Galupo, Justin R. Garcia, Joshua B. Grubbs, Kristyn Kamke, Ian V.
McPhail, Adam Safron, Scott W. Semenyna, and Marie-Pier Vaillancout-Morel.

Two Editorial Board members have been released for time served: Martin Weinberg (who joined the Board in 1982) and Don Strassberg (who joined the Board in 1994). At the young age of 80, Marty, at Indiana University, has decided to edge into retirement. Don, after a mere 43 years at the University of Utah, has done the same. Their contributions to the Journal have been invaluable.

\section{References}

Chivers, M. L. (2017). The specificity of women's sexual response and its relationship with sexual orientations: A review and ten hypotheses. Archives of Sexual Behavior, 46, 1161-1179. https:// doi.org/10.1007/s10508-016-0897-x.

Seto, M. C. (2017). The puzzle of male chronophilias. Archives of Sexual Behavior, 46, 53-58. https://doi.org/10.1007/s10508-016-0922-0.

Zucker, K. J. (2017). Half-way to 90 [Editorial]. Archives of Sexual Behavior, 46, 1. https://doi.org/10.1007/s10508-016-0933-x.

Publisher's Note Springer Nature remains neutral with regard to jurisdictional claims in published maps and institutional affiliations.
Kenneth J. Zucker

ken.zucker@utoronto.ca

1 Department of Psychiatry, University of Toronto, Toronto, ON M5T 1R8, Canada 